\title{
Genetic structure of Bufo bankorensis distinguished by amplified restriction fragment length polymorphism of cytochrome $b$
}

\author{
Chu-Chih Chen ${ }^{\dagger}$, Kou-Wei Li ${ }^{\dagger}$, Teng-Lang Yu, Li-Hsuen Chen, Pei-Yuan Sheu, Yi-Wen Tong, Kao-Jean Huang ${ }^{* \dagger}$ \\ and Ching-Feng Weng ${ }^{*}$
}

\begin{abstract}
Background: Bufo bankorensis is an endemic species in Taiwan, and its populations are geographically and reproductively isolated. However, the distinction of Taiwanese B. bankorensis as a separate species from the Chinese Bufo gargarizans remains in dispute.

Results: A primer set was designed to explore the mitochondrial (mt)DNA cytochrome (Cyt) b sequence (700 bp) of B. bankorensis in 148 individuals collected from 12 locations in Taiwan. After a polymerase chain reaction and sequencing, we found that the nucleotide sequence of Cyt $b$ contained two restricted enzyme sites of BamHI and TspRI. Following BamHI enzyme digestion, samples of B. bankorensis were divided into two clades: western (which were undigested) and eastern (which were digested) clades. Additionally, Cyt $b$ of the western clade of $B$. bankorensis was not cut by BamHI, while it was cut by TspRI into two sublineages. The result infers that at least two broadly divergent phylogroups of $B$. bankorensis exist in Taiwan and are not morphologically distinguishable. Based on the divergent sequence of $C y t b$ and cutting restriction enzymes, these populations were classified into three distinct phylogroups.

Conclusion: Genetically, one (western group 1, uncut by BamHI and cut by TspRI) is most likely B. gargarizans, a second one (western group 2, uncut by both BamHI and TspRI) is B. bankorensis, and a third one (eastern clade, cut by BamHI but not cut by TspRI) could be a new subspecies. All three phylogroups were found in some areas, suggesting that they are sympatric, not allopatric.
\end{abstract}

Keywords: Cytochrome b; Restriction enzyme; Sympatry; Bufo bankorensis; B. gargarizans

\section{Background}

There are many species of Anura in Taiwan. They are identified and classified into five families: the Bufonidae, Hylidae, Microhylidae, Ranidae, and Rhacophoridae. The Bufonidae is one of the most species-rich families of anurans with more than 550 species in approximately 50 recognized genera (Frost 2011). As is known from the literature, Bufo bufo is in Europe, Bufo gargarizans is in mainland Asia, Bufo japonicus is restricted to Japan, and Bufo miyakonis is found in Miyako Island, Japan (Igawa et al. 2006). Interestingly, in the Bufonidae, only two species

\footnotetext{
*Correspondence: kj_huang@mail.ndhu.edu.tw; cfweng@mail.ndhu.edu.tw ${ }^{\dagger}$ Equal contributors

Department of Life Science and Institute of Biotechnology, National Dong Hwa University, Hualien 974, Taiwan
}

(Bufo bankorensis and Bufo melanostictus) are found in Taiwan (Li et al. 2006). B. melanostictus is a common toad in Asia. B. bankorensis is widely distributed in the island of Taiwan at $0 \sim 3,000 \mathrm{~m}$ in elevation. According to the classification of previous studies (Kawamura et al. 1980, 1982; Nishioka et al. 1990), two subspecies of $B$. gargarizans, i.e., B. gargarizans and B. bankorensis, are found in Taiwan. Typically, B. bankorensis is placed in the $B$. gargarizans species complex, but no morphological distinction exists (Inger 1972; Matsui 1984; Liu et al. 2000; Fu et al. 2005). The B. gargarizans complex is one of the most common and widely distributed amphibian groups in eastern Asia. Based on reproductive isolation mechanisms elucidated by crossing experiments, toads from Japan, China, and Taiwan are classified as the 
subspecies group Bufo gargarizans japonicus (Kawamura et al. 1980, 1982). B. bankorensis was reclassified as a distinct endemic species in Taiwan although similar to allopatric populations of Bufo andrewsi (Matsui 1986). Moreover, B. bankorensis is one of three clades of B. japonicus (the other two are Bufo japonicus miyakonis in Miyako Island, Japan and the eastern and western groups of the Japanese Bufo japonicus japonicus subspecies group, and $B$. gargarizans in China) (Igawa et al. 2006). Thus, the Bufo taxa of Taiwan, B. bankorensis and B. gargarizans, remain unclear.

Mitochondrial (mt)DNA can be a powerful molecular marker for reconstructing evolutionary lineages of animals (Avise 1994; Kocher and Stepien 1997; Zhao et al. 2011). Many recent phylogenetic studies also applied mtDNA markers to infer the histories of animals with respect to geography, geology, and paleoclimatology (Macey et al. 1998; Mulcahy and Mendelson 2000). Cytochrome (Cyt) $b$, a region of mtDNA, is used to determine phylogenetic relationships between organisms due to its sequence variability (Castresana 2001). In a phylogenetic study of $B$. bufo based on mtDNA (Cyt $b$, transfer ( $\mathrm{t}$ ) RNAs, 12S ribosomal (r)RNA, and 16S rRNA), gene sequences suggested that one group is $B$. bufo in Europe and the other is B. japonicus in the Far East. B. japonicus was later divided into four major clades corresponding to a group consisting of B. gargarizans in China, B. bankorensis in Taiwan, B. miyakonis in Miyako Island, and eastern and western groups of the Japanese $B . j$. japonicus subspecies group (Igawa et al. 2006). The taxonomic status of $B$. bankorensis has been widely debated, and various names, e.g., B. bufo, B. gargarizans, and Bufo vulgaris var. asiatica, have been either recognized as distinct species (Frost 1985; Matsui 1986; Zhao and Adler 1993) or synonymized with $B$. gargarizans which is widely distributed in China (Lue and Chen 1982). The taxonomic status and phylogenetic relationships among populations in eastern Asia are still unclear, and to understand the effects that past geological events had on the evolutionary history, further investigation is necessary (Fu et al. 2005). The debate as to whether the Taiwanese B. bankorensis is a species or subspecies, however, is still ongoing. This study was conducted to analyze the mtDNA Cyt $b$ of B. bankorensis collected from various locations in Taiwan to verify the genetic structure and taxonomic status.

\section{Methods}

\section{Animal collection}

B. bankorensis and Buergeria robusta treatment and capture procedures were performed with permission from the Taroko National Park Administration (permit nos. 0990010921, 0990011963, 1000011365, and 1010011630), approved by the Committee for Animal Experimentation of National Dong Hwa University, and conformed to guidelines of the International Association for the Study of Pain. In total, 148 adult B. bankorensis were collected from 12 locations including Jhuzihu $(n=20)$, Chilan $(n=$ $7)$, Guanwu $(n=8)$, Shueili $(n=6)$, Tungpu $(n=15)$, Tatachia $(n=7)$, Walami $(n=9)$, Motian $(n=21)$, Chukou $(n=$ $8)$, Nanzihsien River $(n=3)$, Meishankou $(n=32)$, and Kenting $(n=12)$ (Table 1, Figure 1). In addition, Buergeria robusta and Rana swinhoana were collected from Shakadang Creek, a low-elevation area in Taroko National Park (Hualien, Taiwan). B. melanostictus was collected on our school campus in National Dong-Hwan University (Hualien, Taiwan). B. gargarizans was obtained from Shangai (China). Buergeria robusta and $R$. swinhoana were used as outgroups. In our previous study, we determined that the population of

Table 1 Summary of the sample size in each location

\begin{tabular}{|c|c|c|c|c|c|}
\hline & Location & Latitude and longitude & Sample size & Western clade & Eastern clade \\
\hline 1 & Jhuzihu & $25.18^{\circ} \mathrm{N}, 121.54^{\circ} \mathrm{E}$ & 20 & 20 & \\
\hline 2 & Chilan & $24.58^{\circ} \mathrm{N}, 121.38^{\circ} \mathrm{E}$ & 7 & 7 & \\
\hline 3 & Guanwu & $24.50^{\circ} \mathrm{N}, 121.11^{\circ} \mathrm{E}$ & 8 & 8 & \\
\hline 4 & Shueili & $23.81^{\circ} \mathrm{N}, 120.85^{\circ} \mathrm{E}$ & 6 & 6 & \\
\hline 5 & Tungpu & $23.55^{\circ} \mathrm{N}, 120.91^{\circ} \mathrm{E}$ & 15 & 15 & \\
\hline 6 & Tatachia & $23.49^{\circ} \mathrm{N}, 120.89^{\circ} \mathrm{E}$ & 7 & 7 & \\
\hline 7 & Walami & $23.35^{\circ} \mathrm{N}, 121.19^{\circ} \mathrm{E}$ & 9 & 1 & 8 \\
\hline 8 & Kenting & $21.94^{\circ} \mathrm{N}, 120.80^{\circ} \mathrm{E}$ & 12 & 12 & \\
\hline 9 & Motian & $23.19^{\circ} \mathrm{N}, 121.02^{\circ} \mathrm{E}$ & 21 & & 21 \\
\hline 10 & Chukou & $23.44^{\circ} \mathrm{N}, 120.59^{\circ} \mathrm{E}$ & 8 & 6 & 2 \\
\hline 11 & Nanzihsien River & $23.45^{\circ} \mathrm{N}, 120.90^{\circ} \mathrm{E}$ & 3 & 3 & \\
\hline \multirow[t]{2}{*}{12} & Meishankou & $23.27^{\circ} \mathrm{N}, 120.83^{\circ} \mathrm{E}$ & 32 & 30 & 2 \\
\hline & Total & & 148 & 115 & 33 \\
\hline
\end{tabular}




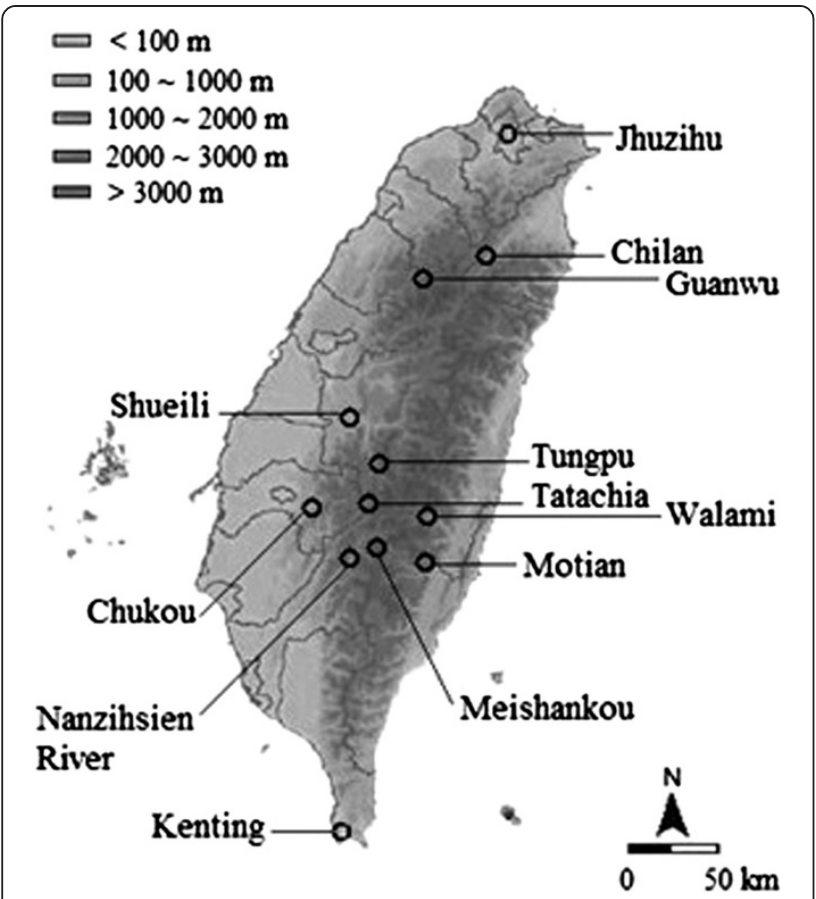

Figure 1 Sampling locations of B. bankorensis in Taiwan.

B. bankorensis could be divided into two major clades (western and eastern clades) following a phylogenetic analysis of haplotypes from a control region (D-loop) sequence (unpublished data).

\section{Preparation of genomic DNA by B. bankorensis mtDNA extraction}

Animals were first placed on ice in a bucket causing them to pass out in accordance with the Animal Protection Law for animal welfare. Next, $20 \sim 30 \mathrm{mg}$ of muscle tissue was excised from each animal. The QuickExtract $^{\mathrm{TM}}$ DNA Extraction Solution (Epicentre, Madison, WI, USA) was used to extract the muscle tissue following the manufacturer's instructions. The muscle was cut into pieces in GT buffer, $20 \mu \mathrm{L}$ of proteinase $\mathrm{K}$ was added, and then it heated to $60^{\circ} \mathrm{C}$ for $10 \mathrm{~min}$. Next, $500 \mu \mathrm{L}$ of GBT buffer was added to the vial and heated to $60^{\circ} \mathrm{C}$ for $10 \mathrm{~min}$, followed by the addition of $500 \mu \mathrm{L}$ of $100 \%$ absolute ethanol to precipitate the DNA. Finally, $750 \mu \mathrm{L}$ of the mixture was loaded onto a GD column (Epicentre) for filtering, and the filtrate was centrifuged at 13,000 rpm for $1 \mathrm{~min}$. The previous steps were repeated on the remaining mixture. Then, $400 \mu \mathrm{L}$ of W1 buffer was added to the GD column, and the filtrate was centrifuged at 13,000 rpm for 30 s. Next, $600 \mu \mathrm{L}$ of wash buffer (ethanol added) was added to the GD column, the filtrate was centrifuged at $13,000 \mathrm{rpm}$ for $30 \mathrm{~s}$ again, and the mixture was subjected to further centrifugation at $13,000 \mathrm{rpm}$ for $30 \mathrm{~min}$. The filtrate of the GD column was put into a new 1.5-mL Eppendorf vial, and $100 \mu \mathrm{L}$ of elution buffer or double-distilled (dd) $\mathrm{H}_{2} \mathrm{O}$ (previously preheated at $60^{\circ} \mathrm{C}$ ) was added to dissolve the DNA. After standing for $5 \mathrm{~min}$, the vial was centrifuged at $13,000 \mathrm{rpm}$ for $30 \mathrm{~s}$. The remaining solution contained the DNA. The DNA solution was stored at $-20^{\circ} \mathrm{C}$, or polymerase chain reaction (PCR) amplification was carried out immediately.

\section{PCR amplification}

In total, $25 \mu \mathrm{L}$ in the PCR vial contained $1 \mu \mathrm{L}$ of genomic DNA, $1 \mu \mathrm{L}$ of 10 pmol primers (Table 2), $2.5 \mu \mathrm{L}$ of 10× PCR buffer, $2 \mu \mathrm{L}$ of dNTP, and $1 \mathrm{U}$ Taq (R001A, Takara Bio, Otsu, Japan) with $\mathrm{ddH}_{2} \mathrm{O}$ added to reach $25 \mu \mathrm{L}$ with adequate vortexing and centrifuging. The vial was heated to $94^{\circ} \mathrm{C}$ for $5 \mathrm{~min}$, followed by 35 cycles of heat denaturation at $94^{\circ} \mathrm{C}$ for $30 \mathrm{~s}$, primer annealing at $45^{\circ} \mathrm{C}$ for $30 \mathrm{~s}$, and DNA extension at $72^{\circ} \mathrm{C}$ for $1 \mathrm{~min}$ in a PCR machine (ASTEC PC802, GMB, Banciao, New Taipei City, Taiwan), with a final amplification step at $72^{\circ} \mathrm{C}$ for $10 \mathrm{~min}$. Moreover, $1.5 \%$ agarose gel electrophoresis was employed to analyze the products, which were visualized by SYBR Safe DNA gel stain (S33102, Invitrogen $^{\mathrm{TM}}$, Life Technologies, Taipei, Taiwan).

\section{Sequencing Cyt b}

After gel electrophoresis, PCR products were extracted with a DNA gel extraction mini kit (Geneaid, Agoura Hills, CA, USA) and selected for DNA sequencing analysis (Genomics BioSci \& Tech, Taipei, Taiwan). The isolated and sequenced nucleotide fragments $(n=148,700 \mathrm{bp})$ of B. bankorensis were blasted by a Basic Local Alignment Search Tool (BLAST, National Center for Biotechnology Information, National Library of Medicine, National Institutes of Health, Bethesda, MD, USA) to confirm validation of the cloned sequences. Based on these sequences, restriction enzyme digestion of DNA (vers. 711, www.biophp.org) was used to find restriction sites such as BamHI and TspRI.

\section{BamHI and TspRI restriction sites confirmed with an agarose gel electrophoresis analysis}

In total, $10 \mu \mathrm{L}$ of enzymatic digestion reaction contained $4 \mu \mathrm{L}$ of PCR products, $1 \mu \mathrm{L}$ of $10 \times$ buffer E, $1 \mu \mathrm{L}$ of $10 \times$ bovine serum albumin, and $1 \mu \mathrm{L}$ of BamHI (BioLab, Taigen, Taipei, Taiwan) or TspRI (BioLab), and $\mathrm{dd}_{2} \mathrm{O}$ was added to reach $10 \mu \mathrm{L}$ with vortexing. The digestion reaction was conducted at $37^{\circ} \mathrm{C}$ for $2 \mathrm{~h}(\mathrm{BamHI})$ or $65^{\circ} \mathrm{C}$ for $4 \mathrm{~h}(T s p \mathrm{RI})$. After digestion, $5 \mu \mathrm{L}$ of products was electrophoresed on a $1.5 \%$ agarose gel for $30 \mathrm{~min}$ at $100 \mathrm{~V}$, photographed, and archived.

Table 2 Sequences of cytochrome (Cyt) $b$ primers

\begin{tabular}{lll}
\hline Primer & Sequence & Amplicon size \\
\hline Bu_Cyb-F & 5'-ACCGCCGACACATCCATAGC-3' & $700 \mathrm{bp}$ \\
Bu_Cyb-R & 5'-CGAGAATAGCATAGGCGAACAAGA-3' & \\
\hline
\end{tabular}

Accession number: AY247260. 


\section{(A) Alignments}

Majority

CATATCTGCCGAGATGTAAACAACGGCTGGCTGCTTCGCAACCTTCATGCAAATGGCGCCTCATTCTICTTCATCTGCATCTACCTCCACATCGGACGGG

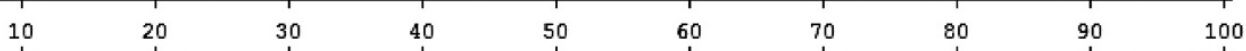

B.bankorensis 1 CATATCTGCCGAGATGTAAACAACGGCTGGCTGCTTCGCAACCTTCATGCAAATGGCGCCTCATTCTTCTTCATCTGCATITACCTCCACATCGGACGGG

B.bankorensis 2 CATATCTGCCGAGATGTAAACAACGGCTGGCTGCTTCGCAACCTTCATGCAAATGGCGCCTCATTCTTCITCATCTGCATCTACCTCCACATCGGGCGGG 100

B.gargarizans CATATCTGCCGAGATGTAAACAACGGCTGGCTGCTTCGCAACCTTCATGCAAATGGCGCCTCATTCTTCTTCATCTGCATCTACCTCCACATCGGACGGG 100

Majority

GIATATACTATGGCTCCTICTIATICAAAGAAACTTGAAATATTGGTGTCATICTCCIATTTCTGGTCATAGCTACAGCATTCGTGGGCTACGTCCITCC

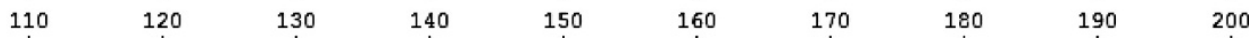

B.bankorensis 1 GTATGTACTATGGCTCCTTCTTATTCAAAGAAACTTGAAATATTGGIGTCATTCTCCTATTTCTGGTCATAGCTACGGCATTCGTAGGCTATGTCCTTCC 200

B.bankorensis 2 GIATATACTATGGCTCCITCTTATTCAAAGAAACTTGAAATATTGGTGTCATTCTCCTATTTCTGGTCATAGCTACAGCATTCGIGGGCTACGTCCTICC 200

B.gargarizans GTATATACTATGGCTCCTTCTTATTCAAAGAAACTTGAAATATTGGIGTCATTCTCCTATTTCTGGTCATAGCTACAGCATTCGIGGGCTACGTCCTICC 200

Majority AIGGGGACAAATATCITICIGGGGGGCAACTGITATTACAAACCITCIITCCGCIGCCCCCIATATCGGAACTGAACITGITCAGTGAATCIGAGGGGG

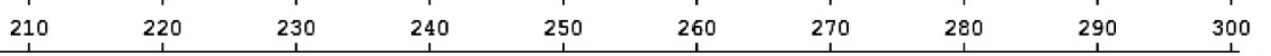

B.bankorensis 1 ATGGGGACAAATATCTTTCTGAGGGGCAACCGTTATTACAAACCTTCTCTCCGCTGCCCCCTATATTGGAACTGAACTTGTTCAATGAATCTGAGGGGGC

B.bankorensis 2 ATGGGGACAAATATCTTTCTGGGGGGCAACTGTTATTACAAACCTTCTTTCCGCTGCCCCCTATATCGGAACTGAACTTGITCAGTGAATCTGAGGGGG 300

B.gargarizans ATGGGGACAAATATCCTTCTGGGGGGCAACIGTTATTACAAACCTTCTTTCCGCTGCCCCCTATATCGGAACTGAACTTGITCAGTGAATCTGAGGGGGC 300

Majority ITITCAGIAGACAACGCAACTCIAACACGAITITITACATITCACITIATCCIGCCGITIAITATTGCAGGCGCITCCATGCITCACCITCTAITITIAC

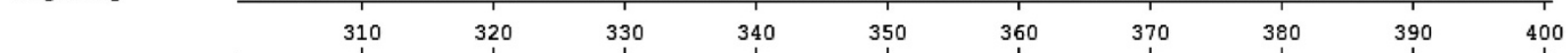

B.bankorensis 1 TITTCAGTAGACAACGCAACTCTAACACGATTTTTTACATTTCACTTTATCCTACCGTTTATCATTGCAGGCGCCTCCATACTTCACCTTCTATTTTTAC

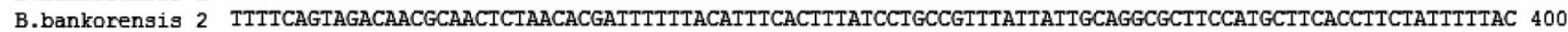

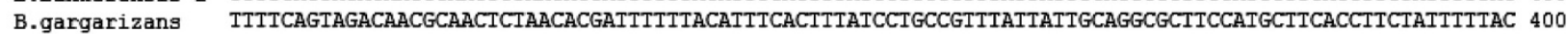

Majority AICAAACAGGGTCCTCIAACCCAACAGGCCITAACCCCAACTITGACAAGATCCCCITCCACGCCIATTACTCCTACAAAGATCTCITCGGCITCGCAAT

$\begin{array}{lllllllll}410 & 420 & 430 & 440 & 450 & 460 & 470 & 480 & 490\end{array}$

B.bankorensis $1 \frac{1}{\text { ATCAAACAGGATCCTCTAACCCAACAGGCCTTAACCCCAACTTTGACAAGATCCCTTTCCACGCCTATTACTCCTACAAAGATCTCTTCGGCTTCGCAAT }}$

B.bankorensis 2 ATCAAACAGGGTCCTCTAACCCAACAGGCCITAACCCCAACTICGACAAGATCCCCTICCACGCCTATTACTCCTACAAAGATCTCTTCGGCTICGCAAT 500

B.gargarizans ATCAAACAGGGICCTCTAACCCAACAGGCCITAACCCCAACTTTGACAAGATCCCCTICCACGCCIATTACTCCTACAAAGATCTCTICGGCTICGCAAT 500

Majority TATGCTIGCCCTACTIGCCITACTATCCACTITCGCCCCCAACCTCITAGGTGACCCAGACAACTTCACACCAGCTAACCCCTIGGTCACCCCACCACAC

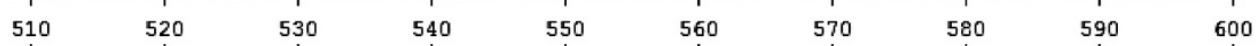

B.bankorensis $1 \frac{1}{\text { TATACTTGCCCTACTTGCCTIACTATCCACCTTCGCCCCCAACCTCITAGGTGACCCAGACAACTTCACACCGGCTAACCCCTTGGTCACCCCACCACAC }}$ 600

B.bankorensis 2 TATGCTTGCCCIACTTGCCTIACTATCCACITTCGCCCCCAACCICITAGGTGACCCAGACAACITCACACCAGCIAACCCCITGGICACCCCACCACAC 600

B.gargarizans TATGCTTGCCCTACITGCCTTACTATCCACITTCGCCCCCAACCTCITAGGTGACCCAGACAACITCACACCAGCTAACCCCTIGGICACCCCACCACAC 600

Majority $\quad$ AICAAGCC

B.bankorensis $1 \overline{\text { ATCAAGCC }}$

B.bankorensis 2 ATCAAGCC

B.gargarizans ATCAAGCC

\section{(B) BamHI site}

Majority ATCAAACAKGGTCCTCTAACCCAACAGGCCTTAACCCCAACTTTGACAAGATCCCCTTCCACGCCTATTACTCCTACAAAGATCTCTTCGGCTTCGCAAT

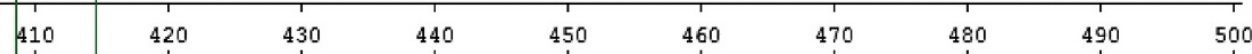

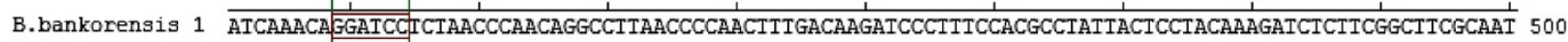

B.bankorensis 2 ATCAAACAGGGTCCTCTAACCCAACAGGCCTTAACCCCAACTTCGACAAGATCCCCTICCACGCCTATTACTCCTACAAAGATCTCTTCGGCTTCGCAAT 500

B.gargarizans ATCAAACA GGGTCCTCTAACCCAACAGGCCTTAACCCCAACITTGACAAGATCCCCTICCACGCCTATTACTCCTACAAAGATCTCTICGGCTICGCAAT 500

Figure 2 Alignments of nucleotide sequence and the BamHI site. Alignments of nucleotide sequence of Cyt $b$ of B. bankorensis and B. gargarizans (A) and the BamHI site (GGATCC) of the Cyt $b$ sequence (B). The alignments were performed with DNA Star. B. bankorensis 1 and 2 are from the Walami area (labeled location number 7 in Table 1).

\section{Phylogenetic analysis}

A haplotype genealogy was constructed using an unrooted neighbor-joining (NJ) algorithm and a bootstrap method with 1,000 replicates using the software MEGA vers. 4.0 (Biodesign Institute, Center for Evolutionary Functional Genomics, Tempe, AZ, USA). B. japonicus was used as an outgroup.

\section{Results}

The Cyt $b$ primer set was applied to run the PCR with DNA of B. bankorensis, B. melanostictus, B. gargarizans, Buergeria robusta, and $R$. swinhoana. Figure 2 illustrates alignments of nucleotide sequences of Cyt $b$ of $B$. bankorensis, B. gargarizans, and Buergeria robusta. Only PCR 
products of B. bankorensis, B. gargarizans, and Buergeria robusta were amplified, and the size of the band was about $700 \mathrm{bp}$, but $R$. swinhoana was not amplified. Figure 3A presents the results of Cyt $b$ PCR products. Based on the Cyt $b$ sequence, the BamHI restriction site was found at $410 \sim 420$ of 700 bp (Figure 3B). After digestion with the BamHI restriction enzyme, the mtDNA of B. bankorensis was divided into two types, and electrophoretic results are shown in Figure 3B. $B$. bankorensis populations were divided into two types based on whether the sequence was cut or not. $B$. bankorensis 1 (Bu1) and $\mathrm{Bu} 3$ were the eastern group, and $\mathrm{Bu} 2$ was the western group. The distinction between the eastern and western groups depended upon geography because samples were collected from both
DNA was digested by the TspRI enzyme. Moreover, the western clade of $B$. bankorensis was further digested by $T s p$ RI and defined as western clade 1 , while the other one (western clade 2 ) was not (Figure $5 \mathrm{~B}$ ). Therefore, the Cyt $b$ sequence of $B$. bankorensis could be cut by TspRI which was $99 \%$ similar to B. gargarizans, whereas the uncut type was only 97\% similar. Figure 6 illustrates phylogenetic relationships. Surprisingly, western group 1 differed from B. gargarizans and formed a cluster with $B$. gargarizans at $99 \%$ similarity. This result suggests that two B. bankorensis populations (western and eastern clades) exist in Taiwan. Moreover, the western clade had two phylogroups, one of which was possibly genetically related to $B$. gargarizans (western clade 1 ) but morphologically differed, and the other which was still named $B$.

\section{(A) PCR}

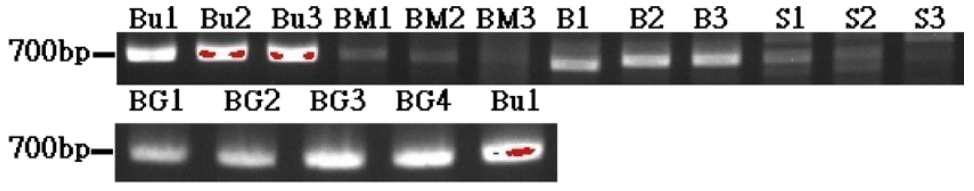

(B)

\section{BamHI}

\section{digestion}

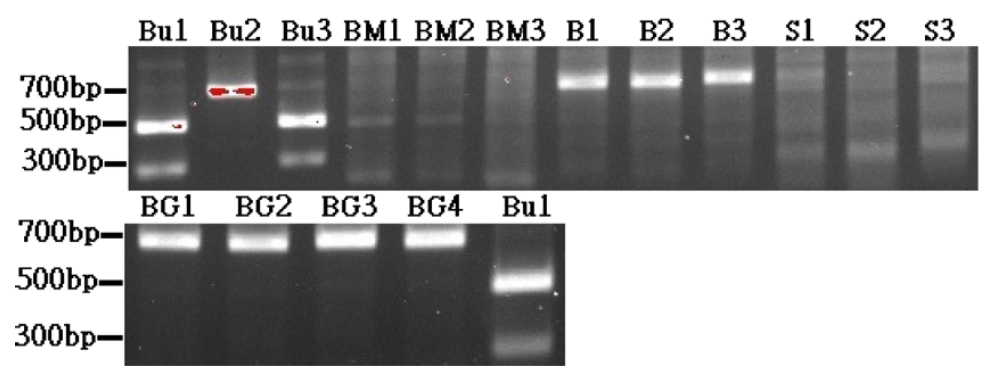

Figure 3 PCR products of various toads and frogs (A), and digestion of BamHI (B). B. bankorensis (Bu), B. melanostictus (BM), B. gargarizans (BG), Buergeria robusta (B), and $R$. swinhoana (S). Buergeria robusta (B) and $R$. swinhoana (S) were used to test the specificity of the primer set. No specific bands were found for $B$. melanostictus or R. swinhoana, and no further sequencing was performed. Bu1 and Bu3 are the eastern clade. Bu2 is the western clade. Bu1, Bu2, Bu3, BM1, BM2, BM3, B1, B2, B3, S1, S2, S3, BG1, BG2, BG3, and BG4 represent different individual samples in each group.

western to eastern parts of the island of Taiwan. The western group was not cut and had a size of about $700 \mathrm{bp}$, while the eastern group was digested into two bands of about 400 and $300 \mathrm{bp}$. In a comparison of Cyt $b$ sequences among eastern and western groups of B. bankorensis with B. gargarizans, only the eastern group of B. bankorensis contained the BamHI restriction site. Additionally, comparison of variations in Cyt $b$ sequences revealed that $99 \%$ similarity was observed for western group 1 of $B$. bankorensis with B. gargarizans (Figure 4A), and 97\% similarity was found for western group 2 of B. bankorensis with B. gargarizans (Figure 4B). The TspRI site of Cyt $b$ among B. gargarizans and $B$. bankorensis is depicted in Figure 5A. B. gargarizans bankorensis (western clade 2). The eastern clade may be a new subspecies in the genetic structure.

\section{Discussion}

After the BamHI assay of the Cyt $b$ sequence of $B$. bankorensis, the presence of two genotypes was observed: one was the Cyt $b$ genotype of the western clade (which was not cut), and the other was the Cyt $b$ genotype of the eastern clade (which was cut). This result was similar to that for the Japanese common toad B. japonicus which is classified into two subspecies, $B . j$. japonicus and Bufo japonicus formosus of western and eastern regions of Japan, respectively (Hase et al. 2012). Interestingly, the similarity of the Cyt $b$ nucleotide sequence 


\section{(A) Western group 1}

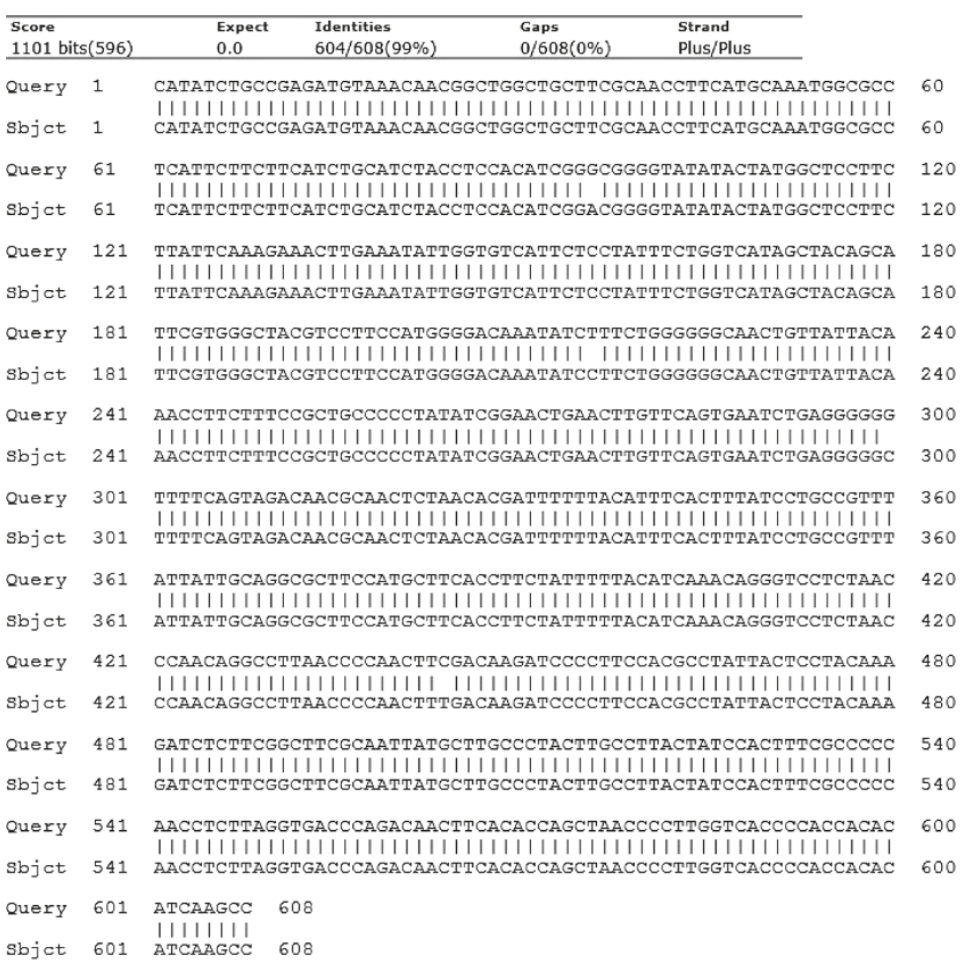

\section{(B) Western group 2}

\begin{tabular}{|c|c|c|c|c|c|c|}
\hline \multicolumn{2}{|c|}{$\begin{array}{l}\text { Score } \\
1007 \text { bits(545) }\end{array}$} & $\begin{array}{l}\text { Expect } \\
0.0\end{array}$ & $\begin{array}{l}\text { Identities } \\
587 / 608(97 \%)\end{array}$ & $\begin{array}{l}\text { Gaps } \\
0 / 608(0 \%)\end{array}$ & $\begin{array}{l}\text { Strand } \\
\text { Plus/Plus }\end{array}$ & \\
\hline 1ery & & \multicolumn{4}{|c|}{ 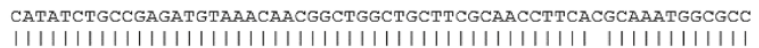 } & 60 \\
\hline ojct & 1 & \multicolumn{5}{|c|}{ CATATCTGCCGAGATGTAAACAACGGCTGGCTGCTTCGCAACCTTCATGCAAATGGCGCC } \\
\hline 1ery & 61 & \multirow{2}{*}{\multicolumn{4}{|c|}{$\begin{array}{l}\text { TCATTCTTCTTCATCTGCATATACCTCCACATCGGACGGGGATGTATTATGGCTCCTTC } \\
11111111111111111111111111111111111111111111111111111111111111111111111111 \\
\text { TCATTCTTCTTCATCTGCATCTACCTCCACATCGGACGGGGATATACTATGGCTCCTTC }\end{array}$}} & \\
\hline jet & 61 & & & & & \\
\hline ery & 121 & \multirow{2}{*}{\multicolumn{4}{|c|}{$\begin{array}{l}\text { TTATTCAAAGAAACTTGAAATATTGGTGTCATTCTCCT } \\
1111111111111111111111111111111111 \\
\text { TTATTCAAAGAAACTTGAAATATTGGTGTCATTCTCCT }\end{array}$}} & \\
\hline jet & 121 & & & & & \\
\hline 1ery & 181 & \multirow{2}{*}{\multicolumn{4}{|c|}{ 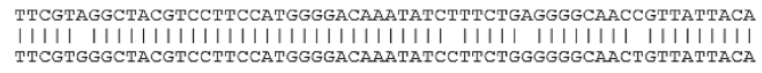 }} & \\
\hline jict & 181 & & & & & \\
\hline ery & 241 & \multirow{2}{*}{\multicolumn{4}{|c|}{ 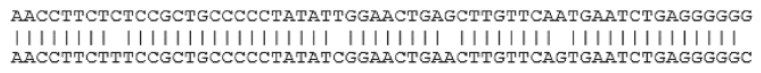 }} & \\
\hline ct & & & & & & \\
\hline ery & & \multirow{2}{*}{\multicolumn{4}{|c|}{ 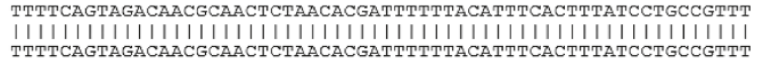 }} & \\
\hline jet & 3 & & & & & \\
\hline ery & & \multirow{2}{*}{\multicolumn{4}{|c|}{ 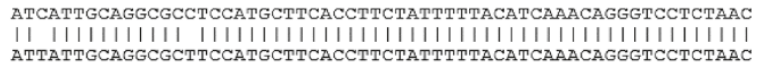 }} & \\
\hline jet & 36 & & & & & \\
\hline ery & 421 & \multirow{2}{*}{\multicolumn{4}{|c|}{$\begin{array}{l}\text { CCAACAGGCCTTAATCCCAACT } \\
\text { IIIIIIIIIIIIIIIIIIIIIIII } \\
\text { CCAACAGGCCTTAACCCCAACT }\end{array}$}} & \\
\hline jet & 42 & & & & & \\
\hline$r v$ & 48 & \multirow{2}{*}{\multicolumn{4}{|c|}{$\begin{array}{l}\text { GATCTCTTCGGCTTCGCAATTATAC } \\
\text { |IIIIIIIIIIIIIIIIIIIIIII } \\
\text { GATCTCTTCGGCTTCGCAATTATGC }\end{array}$}} & \\
\hline bjet & 481 & & & & & \\
\hline ery & 5 & \multirow{2}{*}{\multicolumn{4}{|c|}{ 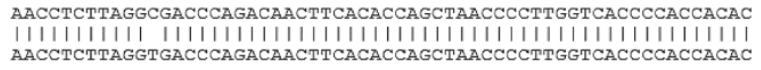 }} & \\
\hline ojct & 54 & & & & & \\
\hline dery & 6 & \multirow{2}{*}{$\begin{array}{l}\text { ATCAAGCC } \\
11111111 \\
\text { ATCAAGCC }\end{array}$} & & & & \\
\hline & 601 & & & & & \\
\hline
\end{tabular}

Figure 4 Alignments of Cyt $\boldsymbol{b}$ sequences. Alignments of Cyt $b$ sequences between western clade 1 of B. bankorensis and B. gargarizans (A), and western clade 2 of B. bankorensis and B. gargarizans (B). The alignment of nucleotide sequences was prepared using Mega 4 and NCBI blast. 


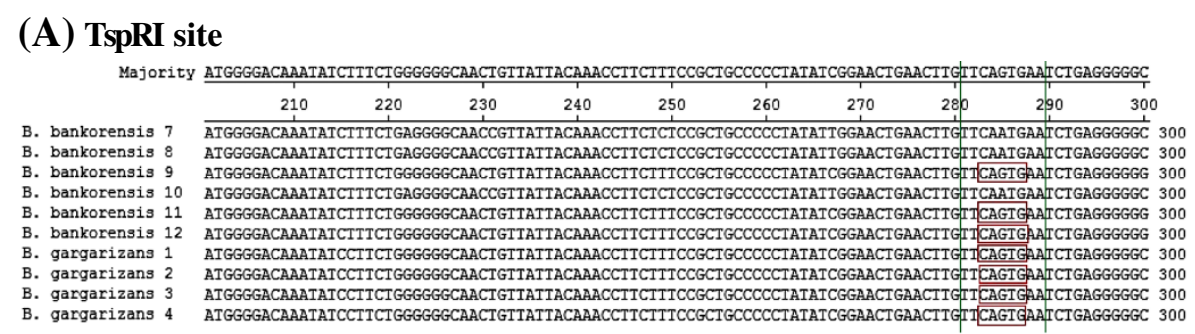

\section{(B) TspRI Digestion}

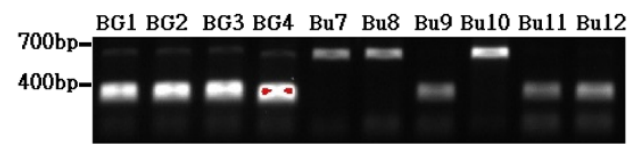

Figure 5 The TspRI site and digestion of TspRI. (A) The TspRI site (NNCASTGNN in the green box; N = A, T, C, G; $S=C, G$ ) of cytochrome $b$ in the western clade and B. gargarizans. (B) Digestion of TspRl in B. bankorensis (Bu) and B. gargarizans (BG). BG1, BG2, BG3, BG4, Bu7, Bu8, Bu9, Bu10, Bu11, and Bu12 represent different individual samples in each group. BG1, BG2, BG3, BG4 are from China. Bu7, Bu8, Bu9, Bu10, Bu11, and Bu12 are from the Jhuzihu area, Taiwan (labeled location number 1 in Table 1).

was $99 \%$ between the western clade 1 and B. gargarizans, and they were further digested by TspRI, whereas the other western clade 2 was $97 \%$ similar with $B$. gargarizans and was not cut by TspRI. Recent molecular phylogenetic studies (Liu et al. 2000; Fu et al. 2005) supported the two-species classification by synonymizing $B$. bankorensis with B. gargarizans. Our data (Figure 6) revealed that $B$. bankorensis was proposed to be $B$. japonicus which was divided into three major clades corresponding to a group consisting of Bufo japonicus gargarizans in China, Bufo japonicus bankorensis in Taiwan, and B. j. miyakonis in Miyako Island, Japan (Igawa et al. 2006); $B$. bankorensis was also postulated to be an endemic species in Taiwan (Fu et al. 2005). From ecological view, the range of certain species is associated with habitat conditions. In the current study, the size and age at metamorphosis of tadpoles vary among individuals from the same species in different habitats in a relatively small area, suggesting that distributions of different species depend upon adaptation to extreme conditions (Goldberg et al. 2012). Moreover, we found that bankorensis toads formed a complex from the restriction enzyme and phylogenetic relationship, but more detailed assessments including morphology and physiology need to be carried out in the future work to identify subspecies or new species existing.

A previous report found that B. japonicus in the Far East was divided into two groups, one of which became two subspecies: B. j. gargarizans in China and Taiwan

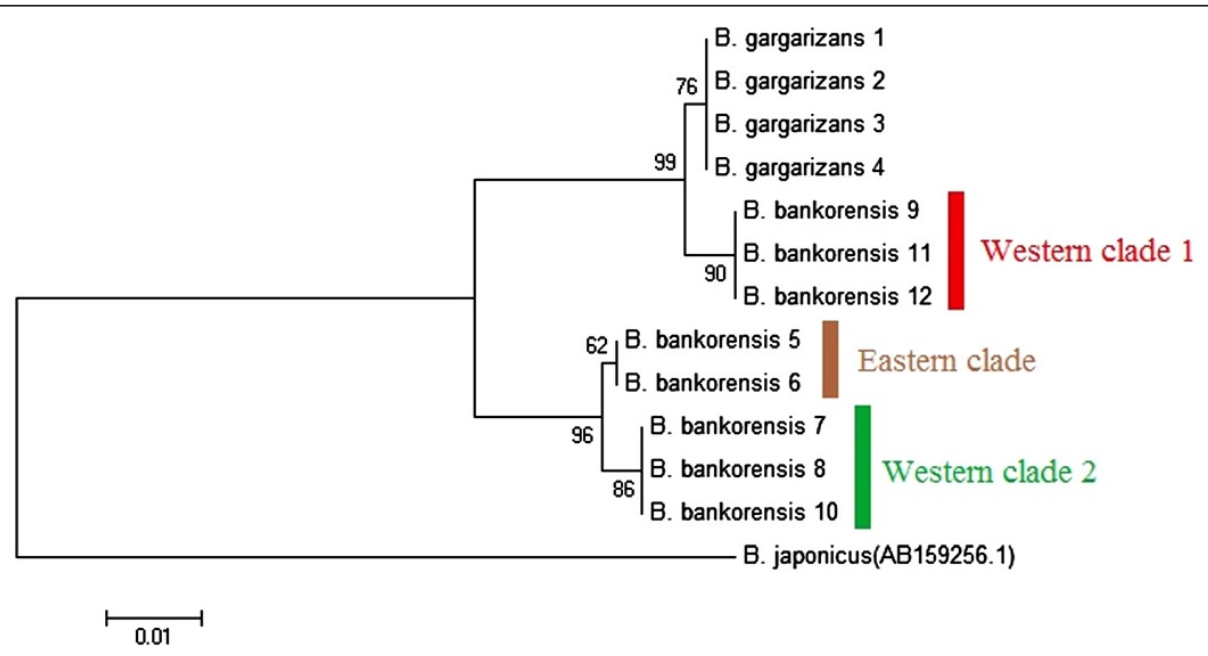

Figure 6 Phylogenetic tree. The neighbor-joining phylogenetic tree of cytochrome $b$ of the eastern and western clades of $B$. bankorensis, B. gargarizans, and B. japonicus (sequence AB159256.1 from NCBI GenBank). The phylogenetic tree was analyzed by Mega 4. B. japonicus was used as an outgroup. B. gargarizans (BG1, BG2, BG3, and BG4) was from China. The eastern (Bu5 and Bu6) and western clades (Bu7, Bu8, Bu9, Bu10, Bu11, and Bu12) were from the Jhuzihu area, Taiwan (labeled location number 1 in Table 1). 
and B. j. miyakonis in Miyako Island, Japan, while the other group became four subspecies on the eastern and western groups of Japanese B. j. japonicus, Hakodate, and Yaku Island, Japan (Nishioka et al. 1990). However, in past phylogenetic studies, sampling was limited to a small sample size (mostly one or two locations and did not include samples from eastern Taiwanese B. Bankorensis populations). Given that populations resembling B. gargarizans occur on an isolated island (Taiwan Island), there are two alternative hypotheses that might explain this pattern: (1) B. bankorensis populations are from a single lineage of $B$. gargarizans that subsequently dispersed to the island and became isolated, or (2) B. bankorensis independently evolved multiple times as $B$. gargarizans colonized the island. The present work proved the existence of two species (B. gargarizans and B. bankorensis) in Taiwan using a simple restriction enzyme (TspRI). From our data and according to previous reports, there are two subspecies, Bufo gargarizans gargarizans and Bufo gargarizans bankorensis, in Taiwan (Kawamura et al. 1980, 1982; Nishioka et al. 1990). Furthermore, B. bankorensis was classified in the $B$. gargarizans species complex (Inger 1972; Matsui 1984; Liu et al. 2000; Fu et al. 2005), one of the most common and widely distributed amphibian groups in eastern Asia. The eastern and western groups of B. japonicus were divided into several subclades that tended to reflect the regionspecific geographic distribution of all localities except $B . j$. japonicus from Hakodate, Japan (Igawa et al. 2006). The western clade of $B$. bankorensis can be distinguished by restriction fragment length polymorphism and the phylogenetic tree, but not by nucleotide homology. This viewpoint suggests that the tree represents homoplasy. This region-specific subclade of the toad, such as western groups 1 and 2, was also found in Taiwanese B. bankorensis. This finding is in agreement with a report by Hase et al. (2012) that an admixed population was observed in the urban Tokyo area that consisted of both native and nonnative B. japonicus subspecies. Conversely, Bufo tibetanus is a morphologically identified species but not genetically diagnosable, which was inferred to be a junior synonym of B. gargarizans (Zhan and Fu 2011). Our results propose that two populations (western and eastern clades) of $B$. bankorensis appear in Taiwan and are classified into three distinct phylogroups: the first is genetically related to $B$. gargarizans, the second should be B. bankorensis, and the third may be considered a new subspecies. In the same area (Tungpu, Taiwan), we also identified two different clades: western clades 1 and 2 . The molecular phylogenetic studies supported B. gargarizans and B. bankorensis being synonymized, and $B$. bankorensis only being a lineage of B. gargarizans (Liu et al. 2000; Fu et al. 2005). This reflects a previous study (Fu et al. 2005) showing that $B$. gargarizans and B. bankorensis may be subspecies if samples were collected at certain locations. The present study postulates that $B$. bankorensis (western clade 1 ) is only a lineage of $B$. gargarizans because they are only genetically identifiable in contrast to having different morphologies. Hence, B. bankorensis is one species and is restricted to Taiwan. Based on our data, all three distinct phylogroups were observed in the wild and were found in some locations, further suggesting that they are sympatric, not allopatric.

\section{Conclusions}

Genetically, one (western group 1, uncut by BamHI and cut by $T_{s} p \mathrm{RI}$ ) is most likely $B$. gargarizans, a second one (western group 2, uncut by both BamHI and Tsp RI) is $B$. bankorensis, and a third one (eastern clade, cut by BamHI but not cut by TspRI) could be a new subspecies. $B$. bankorensis is recognized as one species having different morphologies compared with $B$. gargarizans and is restricted to Taiwan. All three phylogroups were found in some areas, suggesting that they are sympatric, not allopatric.

\section{Competing interests}

The authors declare that they have no competing interests.

\section{Authors' contributions}

C-CC, K-WL, P-YS, and Yi-WT carried out the molecular genetic studies and participated in the sequence alignment. T-LY and L-HC participated in the design of the study and performed the statistical analysis. K-JH and C-FW conceived the study and participated in its design and coordination and drafted the manuscript. All authors read and approved the final manuscript.

\section{Acknowledgments}

This study was supported by funding from Taroko and Yushan National Parks, Taiwan. We would like to thank Yushan National Park staff for their assistance and contributions to the laboratory work. Of course, this work also dedicates a memorial to the frontier heroes and animals during the development of the eastern-western region of Taiwan.

Received: 21 May 2013 Accepted: 12 September 2013

Published: 26 November 2013

\section{References}

Avise JC (1994) Molecular markers, natural history and evolution. Chapman and Hall, New York

Castresana J (2001) Cytochrome b phylogeny and the taxonomy of great apes and mammals. Mol Biol Evol 18:465-471

Frost DR (2011) Amphibian species of the world: an online reference, Vers. 5.5 Available at http://research.amnh.org/vz/herpetology/amphibia/ Accessed 31 Jan. 2011

Frost DRE (1985) Amphibian species of the world: a taxonomic and geographical reference. Allen Press. Inc. and The Association of Systematics Collections, Lawrence, Kansas, p 732

Fu J, Weadick C, Zeng X, Wang Y, Liu Z, Zheng Y, Li C, Hu Y (2005) Phylogeographic analysis of the Bufo gargarizans species complex: a revisit. Mol Phylogenet Evol 37:202-213

Goldberg T, Nevo E, Degani G (2012) Phenotypic plasticity in larval development of six amphibian species in stressful natural environments. Zool Stud 51:345-361

Igawa T, Kurabayashi A, Nishioka M, Sumida M (2006) Molecular phylogenetic relationship of toads distributed in the Far East and Europe inferred from the nucleotide sequences of mitochondrial DNA genes. Mol Phylogenet Evol 38:250-260

Hase K, Shimada M, Nikoh N (2012) High degree of mitochondrial haplotype diversity in the Japanese common toad Bufo japonicus in urban Tokyo. Zool Sci 29:702-708

Inger RF (1972) Bufo of Eurasia. Univ. of Texas Press, Austin, TX 
Kocher TD, Stepien CA (1997) Molecular systematics of fishes. Academic, New York

Li KW, Lee DN, Huang WT, Weng CF (2006) Temperature and humidity alter prolactin receptor expression in the skin of toad (Bufo bankorensis and Bufo melanostictus). Compar Biochem Physiol A Mol Integr Physiol 145:509-516

Liu W, Lathrop A, Fu J, Yang D, Murphy R (2000) Phylogeny of East Asian bufonids inferred from mitochondrial DNA sequences (Anura: Amphibia). Mol Phylogenet Evol 14:423-435

Lue GY, Chen SH (1982) Toad species of Taiwan. In: Chang CH (ed) Amphibians of Taiwan. Natural Press, Taipei, Taiwan, pp 1-190

Macey J, Schulte J, Larson A, Fang Z, Wang Y, Tuniyev B, Papenfuss T (1998) Phylogenetic relationships of toads in the Bufo bufo species group from the eastern escarpment of the Tibetan Plateau: a case of vicariance and dispersal. Mol Phylogenet Evol 9:80-87

Matsui M (1984) Morphometric variation analyses and revision of the Japanese toads (Genus Bufo, Bufonidae). Contrib Biol Lab Kyoto Univ 26:209-428

Matsui M (1986) Geographic variation in toads of the Bufo bufo complex from the Far East, with a description of a new subspecies. Copeia 1986:561-579

Mulcahy DG, Mendelson JR III (2000) Phylogeography and speciation of the morphologically variable, widespread species Bufo valliceps, based on molecular evidence from mtDNA. Mol Phylogenet Evol 17:173-189

Nishioka M, Sumida M, Ueda H, Wu Z (1990) Genetic relationship among 13 Bufo species and subspecies elucidated by the method of electrophoretic analyses. Sci Rep Lab Amphib Biol Hiroshima Univ 10:53-91

Zhan A, Fu J (2011) Past and present: phylogeography of the Bufo gargarizans species complex inferred from multi-loci allele sequence and frequency data. Mol Phylogenet Evol 61:136-148

Zhao E, Adler KE (1993) Herpetology of China. Society for the Study of Amphibians and Reptiles (SSAR), Salt Lake City, Utah 84158-0517, USA, St. Louis, MO

Zhao L, Zheng ZM, Huang Y, Zhou Z, Wang L (2011) Comparative analysis of the mitochondrial control region in Orthoptera. Zool Stud 50:385-393

doi:10.1186/1810-522X-52-48

Cite this article as: Chen et al:: Genetic structure of Bufo bankorensis distinguished by amplified restriction fragment length polymorphism of cytochrome b. Zoological Studies 2013 52:48.

\section{Submit your manuscript to a SpringerOpen ${ }^{\circ}$ journal and benefit from:}

- Convenient online submission

- Rigorous peer review

- Immediate publication on acceptance

- Open access: articles freely available online

- High visibility within the field

- Retaining the copyright to your article

Submit your next manuscript at $\gg$ springeropen.com 